\title{
The Effect of Coaching Support on Kidney Function in Chronic Kidney Disease Patients
}

\author{
Susanti Susanti ${ }^{1 *}$, Difran Nobel Bistara ${ }^{2}$ \\ ${ }^{1}$ Department of Medical Surgical of Nursing, Adi Husada College of Health Sciences, Surabaya, Indonesia; ${ }^{2}$ Department of \\ Medical Surgical of Nursing, Nahdlaltul Ulama University, Surabaya, Indonesia
}

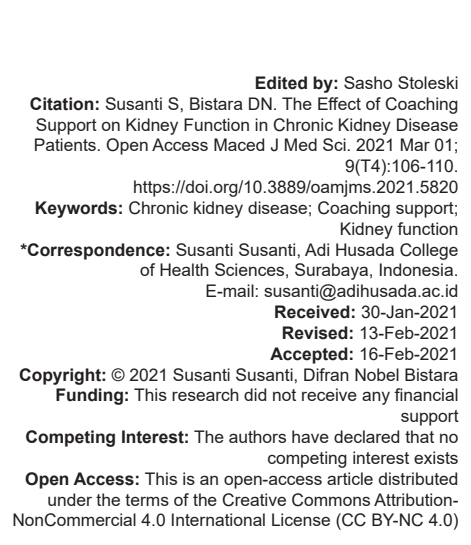

\section{Introduction}

Kidneys have an important role in maintaining fluid volume and distribution in overall body health. Impairment in kidney function could lead to chronic kidney disease (CKD). CKD is a progressive and irreversible impairment of kidney function, causing decreased kidney function. CKD with reduced glomerular filtration rate (GFR) will cause kidney function problems in the form of urea and other nitrogenous wastes retention in the blood circulation. This condition can be a life threatening in CKD patients. There were 60 CKD patients who perform regular visit in outpatient ward in RS Adi Husada Surabaya. Despite regular visit, there are still many CKD patients whose disease get worsen into the next stage, even the end-stage renal disease $(23 \%)$. One of the reasons is because of the low level of adherence to the fluid restriction [1], [2].

In Indonesia, the prevalence of CKD continues to increase every year. According to Indonesian Nephrology Association statistical data, there are 200,000 Indonesians suffering from end-stage CKD every year. Based on the data from the Basic Health
Research in 2018, the prevalence of CKD patients in Indonesia is $0.2 \%$. Indonesian population as many as 104,000 people suffer from CKD and undergo hemodialysis. A preliminary study conducted at Adi Husada Hospital in Surabaya showed that CKD patients had increased every year. In the past 2 years, there has been an increase in the number of CKD patients from 7 in 2017 to 60 CKD patients at the end of 2019. Of this number, 20 people undergoing hemodialysis while the rest were undergoing outpatient care based on medical records of Adi Husada Hospital Surabaya (2019).

Kidney disease in urban populations has linkages with other underlying diseases such as DM, hypertension, and dyslipidemia. Urban population lifestyle forces them to be disciplined in managing their illness. Early symptoms in kidney disease tend to be asymptomatic or mild, making it difficult to be diagnosed only by clinical examination. One of the parameters used to identify kidney disorders is examination of the GFR and urea levels. The GFR test measures the body waste filtration in the blood by the kidneys based on creatinine levels in the blood, age, body size, and gender. This GFR test is needed to determine the appropriate treatment for CKD patients [2], [3]. 
Urea and creatinine are waste products of the body's metabolism. High creatinine levels are 8 times more common in people with hypertension than in other individuals with normal blood pressure. Kidney disease and hypertension can lead to CKD, and if left untreated, it will progress to the end stage of renal disease which requires replacement therapy for kidney function which is known as dialysis or kidney transplantation [4].

Urea and creatinine are chemical compounds that indicate normal kidney function, while creatinine is an endogenous metabolism that is useful for assessing glomerular function. Creatinine is produced and excreted at the same amount in the urine, with a normal value of creatinine $<1.5 \mathrm{mg} / \mathrm{dl}$ and urea $10-50 \mathrm{mg} / \mathrm{dl}$. Urea is a nitrogen product excreted by the kidneys from a protein diet. Urea serum levels provide the best sign for the onset of toxic urea and are a symptom that can be detected compared to creatinine in CKD patients (Miller, 2018). The urea level of CKD patients before hemodialysis is still at an abnormal level, and on average, is also hyperuremic. Urea serum and creatinine levels need to be monitored as an indicator of kidney damage [5].

Kidney function can be maintained to prevent kidney damage progression by controlling sugar levels and controlling blood pressure. Kidney function examination for DM patients with hypertension is effective for early detection of CKD. CKD management by proper intervention related to safe drug use, dietary regulation, fluid restriction, and routine kidney function control by providing coaching support [6].

The coaching support intervention provides health education gradually and continuously to CKD patients and their families by concerning their problems regarding the illness. This intervention is expected to improve awareness of CKD patients and their family about the disease and to improve patient behavior and coping as a support system [7], [8]. The purpose of this study was to identify the effect of coaching support on kidney function in CKD patients.

\section{Methods}

This study design was quasi-experiment with pre-test and post-test with a control group approach. The population in this study were all CKD patients who were treated at Adi Husada Hospital Surabaya from April 2020 to June 2020 with inclusion criteria CKD patients with early stage until Stage 3, CKD patients never had hemodialysis therapy, and the patients were in a stable general condition. Respondents in this study were 40 CKD patients which were taken using consecutive sampling technique. The sample then divided into two groups, namely, the control and treatment groups. The independent variable in this study was coaching support. The dependent variable in this study was kidney function. The data were collected using the GFR and blood urea nitrogen (BUN) observation sheet. Coaching support was provided 4 times to the treatment group for 2 weeks. Data were analyzed using paired t-test and independent t-test with a significance level of $p<0.05$.

\section{Results}

\section{General data (univariate analysis)}

Table of univariate analysis according to age shows that there is no difference in age distribution between the control group and the treatment group. Most of the respondents were in the age group of 56-65 years as many as 8 people (40\%). Based on gender indicates that most of the respondents who participated in this study were female. There was no difference in gender distribution between the control group and the treatment group. Most of the respondents were female as many as 14 people (70\%) in the control group and as many as 17 people (85\%) in the treatment group. Based on last education indicates that there is no difference in education background between the control group and the treatment group. Most of the respondents had senior high school education level, namely, 8 people $(40 \%)$ in the control group and as many as 12 people $(60 \%)$ in the treatment group. Based on illness duration indicates that there is no difference in illness duration between the control and treatment groups. Most of the respondents had been suffering from the illness $<6$ years, namely, 12 people in the control group (60\%) and 11 people in the treatment group (55\%) (Table 1).

\section{Specific data (bivariate analysis)}

\section{The results of the paired-t-test}

The results of the paired t-test between pre and post test of GFR is $p=0.00$ (Table 2). It can be concluded that there is a significant change in GFR before and after the intervention. This is evidenced by the $95 \% \mathrm{Cl}$ mean value in the two groups not involving the number 0 , so the results are said to be significant. In the treatment group, there was an increase in GFR greater than the control group, which was indicated by $t=8.66$. The analysis of BUN shown $p=0.00$ (Table 3 ). It can be concluded that there is a significant change in the BUN value before and after the intervention ( $p$ $<0.05$ ) so. This is evidenced by the $95 \% \mathrm{Cl}$ mean value in the two groups not involving the number 0 , so the results are said to be significant. In the treatment group, there was a decrease in BUN greater than the control group which was indicated by $t=13.97$. 


\section{The result of the independent sample t-test}

The result of the independent sample t-test shows that the difference in the average change in GFR before and after coaching support in the control group and treatment group is 4.62 points. Based on the results of the statistical test of the independent sample t-test, $p=0.00$ was obtained. $p<0.05$, so it can be concluded that there is a significant difference in GFR changes between the control group and the treatment group. The difference in the urea value of the control group and the treatment group between the pre and post treatment support coaching is 21.63 points. Based on the results of the statistical test of the independent sample t-test, $p=0.00$ was obtained. $p<0.05$, so it can be concluded that there was a significant difference in the BUN level change between the control and the treatment group.

\section{Discussion}

The results showed that the treatment group experienced an increase in GFR of 8.66 and a decrease in urea level of 13.97. This change was significant between kidney function before and after coaching support with $p=0.000$. It can be concluded that there was a difference in the kidney function of CKD patients with CKD in the treatment group. In addition, from the results of the analysis, it was concluded that there were significant differences GFR and BUN level between the control and the treatment groups.

Improper management is one of the causes of further kidney damage in CKD patients. The principles of CKD management are fluid restriction and diet regulation. The efforts must be conducted to maintain kidney function and inhibit disease progression. Kidney function was decreased in CKD to the stage of CKD. One of the kidney functions is fluid regulation and electrolyte balance. Fluid restriction can reduce kidney workload so that there is no fluid overload in the body and lungs [9], [10].

Kidney damage in CKD patients will not getting worse if kidneys do not have excessive workload. Kidney workload can be reduced by limiting fluid intake so that kidney function can be optimized at currently stages [1]. This result in accordance with previous research [11] which stated that most of CKD patients do not understand how many fluids intake that should be consumed within $24 \mathrm{~h}$. Most of CKD patients also do not understand how to reduce thirst. Appropriate self-care in managing fluids for $24 \mathrm{~h}$ in CKD patients is $500 \mathrm{ml}+$ the amount of urine that comes out in $24 \mathrm{~h}$. This is in line with Hasneli's research which stated that providing health education about fluid restrictions can stabilize kidney function and prevent further complications [12].
Kidney damage in CKD patients can also be prevented by proper dietary management, one of which is a diet with rich potassium compound. Kidneys function is to regulate electrolyte balance, so dietary control on foods containing potassium must be limited. Limiting foods containing potassium intake can prevent escalation of potassium levels in the blood. Increased levels of potassium in the blood can affect the heart rate. High potassium level of food is found in green fruits and vegetables [1], [4]. The need of vegetables and fruits nutrients for CKD patients can be fulfilled by proper food processing (by soaking and boiling first so that potassium levels decrease) [13]. This is in line with research conducted by Mersal which stated that providing about dietary processing technique and fluid restrictions is effective to prevent further complications in CKD patients undergoing hemodialysis [14].

One of the critical matters in CKD management to optimize treatment is the provision of health education. Providing education can effectively increase the patient's ability to manage their disease [15]. The previous study found that education can increase knowledge and change attitudes but do not change negative perceptions about the disease so that at times it can worsen the patient's condition [16]. This study was in line with the results of Ariyanti's research that self-efficacy training can prevent the progression of kidney damage [6].

Coaching support is an advanced method to help individuals manage their illnesses, especially chronic illness [17]. Coaching support is an intervention that can be provided by the health service provider to help CKD patients to identify issues, beliefs, and concerns that can obstruct or encourage their lifestyle changing or responsibility for their health. Coaching support was provided 4 times to the treatment group for 2 weeks. Coaching support was divided into four steps of therapy. The first step was identified disturbance or problem experienced of the patients; the second step was identified conditions or situations based on experience. The next step, use a family support system, monitor results, and the obstacles and then the last step was evaluating the results and barriers to

Table 1: CKD patients frequency distribution

\begin{tabular}{|c|c|c|c|c|c|c|}
\hline \multirow[t]{2}{*}{ Characteristic } & \multicolumn{2}{|c|}{$\begin{array}{l}\text { Control } \\
\text { group }\end{array}$} & \multicolumn{2}{|c|}{$\begin{array}{l}\text { Intervention } \\
\text { group }\end{array}$} & \multicolumn{2}{|c|}{ Total } \\
\hline & $\mathrm{n}$ & $\%$ & $\mathrm{n}$ & $\%$ & $\mathrm{n}$ & $\%$ \\
\hline \multicolumn{7}{|l|}{ Age (years old) } \\
\hline $46-55$ & 7 & 35 & 6 & 30 & 13 & 32,5 \\
\hline $56-65$ & 8 & 40 & 8 & 40 & 16 & 40 \\
\hline $66-75$ & 5 & 25 & 6 & 30 & 11 & 27,5 \\
\hline \multicolumn{7}{|l|}{ Gender } \\
\hline Male & 6 & 30 & 3 & 15 & 9 & 22.5 \\
\hline Female & 14 & 70 & 17 & 85 & 31 & 77.5 \\
\hline \multicolumn{7}{|l|}{ Last education } \\
\hline Uneducated & 2 & 10 & 1 & 5 & 3 & 7.5 \\
\hline Elementary school & 3 & 15 & 2 & 10 & 5 & 12.5 \\
\hline Junior high school & 4 & 20 & 2 & 10 & 6 & 15 \\
\hline Senior high school & 8 & 40 & 12 & 60 & 20 & 50 \\
\hline $\begin{array}{l}\text { Diploma/Bachelor degree/master } \\
\text { degree }\end{array}$ & 3 & 15 & 3 & 15 & 6 & 15 \\
\hline \multicolumn{7}{|l|}{ Illness duration } \\
\hline$<6$ years & 12 & 60 & 11 & 55 & 23 & 57.5 \\
\hline$>6$ years & 8 & 40 & 9 & 45 & 17 & 42.5 \\
\hline
\end{tabular}


Table 2: Changes in GFR and BUN level before and after coaching support

\begin{tabular}{|c|c|c|c|c|c|c|}
\hline \multirow{3}{*}{$\begin{array}{l}\text { Characteristic } \\
\text { GFR }\end{array}$} & Respondent & Before (Mean \pm SD) & After (Mean \pm SD) & $95 \% \mathrm{Cl}$ & $t$ & $p^{*}$ \\
\hline & Control group & $17.25 \pm 6.03$ & $18.67 \pm 7.71$ & $-1.42 ;-1.68$ & 3.10 & 0.00 \\
\hline & Treatment group & $25.01 \pm 8.07$ & $29.73 \pm 12.01$ & $-4.72 ;-3.94$ & 8.66 & 0.00 \\
\hline \multirow[t]{2}{*}{ BUN } & Control group & $55.34 \pm 12.73$ & $34.01 \pm 9.03$ & 21,$33 ; 3.70$ & 25.03 & 0.01 \\
\hline & Treatment group & $63.22 \pm 16.08$ & $51.26 \pm 14.07$ & $11.96 ; 2.01$ & 13.97 & 0.00 \\
\hline
\end{tabular}

GFR: Glomerular filtration rate, BUN: Blood urea nitrogen. ${ }^{*} \mathrm{p}<0.05$ based on paired t-test.

Table 3: GFR and BUN level difference before and after coaching support

\begin{tabular}{|c|c|c|c|c|c|}
\hline Difference value & $\begin{array}{l}\text { Control } \\
\text { group }(\text { Mean } \pm S D)\end{array}$ & $\begin{array}{l}\text { Treatment } \\
\text { group (Mean } \pm S D \text { ) }\end{array}$ & $\begin{array}{l}\text { Mean } \\
\text { difference }\end{array}$ & $95 \% \mathrm{Cl}$ & $\mathrm{p}^{*}$ \\
\hline $\begin{array}{l}\text { Kidney } \\
\text { physiology: GFR }\end{array}$ & $3.71 \pm 1.74$ & $5.53 \pm 2.93$ & 4.62 & $\begin{array}{l}-1.82 \\
-1.19\end{array}$ & 0.00 \\
\hline Ureum of value & $24.00 \pm 8.98$ & $19.26 \pm 6.97$ & 21.63 & $\begin{array}{l}4.74 \\
2.01\end{array}$ & 0.00 \\
\hline
\end{tabular}

the use of support sources both within and outside the family [18].

Providing coaching support can affect the behavior of people with CKD to carry out CKD management according to the things that have been suggested by the coach [19]. Coaching support is in the form of education for people with CKD by showing direct intervention and offering indirect intervention by involving family participation [7], [8]. The purpose of coaching support is focused on improving coping with CKD sufferers by involving family participation.

Providing coaching support begins with a contract with the family to establish an agreement to commit to changing a positive viewpoint regarding the management of CKD patients through improving the knowledge of CKD management and commitment to behavior improvement [20], [21]. Based on the characteristics of respondents, most of whom are the elderly, the success of the coaching support intervention cannot be separated from the active role of the family, and the availability of family time to accompany them. Patients sometimes forget to take medication and the medicine is still there so that the patient delays the time for control. Another reason for the delay in control is because no one will take them to the health service. Support and motivation should provided by the surrounding environment, especially family.

\section{Conclusion}

Coaching support has a significant effect in changing the family's ability to care for people with CKD so that sufferers also have behavioral improvements in diet regulation and fluid restrictions that can improve kidney function. Giving coaching support should be given at an early stage instead give a more precise meaning for CKD patients can maintain good kidney function and can maintain stage renal impairment at any stage to improve the quality of life of patients.
This research has passed research ethical clearance conducted at Adi Husada Hospital Surabaya. Before conducting the study, the researcher explained the purpose of the study and asked the respondent for approval, further explaining in the data observation filling out no need to provide names and guarantee the confidentiality of data from respondents. The ethical clearance carried out already contains informed consent, anonymity, autonomy, confidentiality, beneficence, nonmaleficence, veracity, and justice.

\section{Acknowledgments}

Thank you to all respondents and to those who have helped in completing this research until the compilation of this manuscript. Thank you to the University of Nahdlaltul Ulama Surabaya and Adi Husada College of Health Sciences for providing much encouragement and support so that this research can be carried out and all those who helped a lot. May God bestow grace and convenience for all of us.

\section{References}

1. Clarke AL, Yates T, Smith AC, Chilcot J. Patient's perceptions of chronic kidney disease and their association with psychosocial and clinical outcomes: A narrative review. Clin Kidney J. 2016;9(3):494-502. https://doi.org/10.1093/ckj/sfw014 PMid:27274839

2. National Kidney Disease Education Program. Chronic Kidney Disease (CKD) and Diet: Assessment, Management, and Treatment Revised, NKDEP; 2015.

3. PERNEFRI. $7^{\text {th }}$ Report of Indonesian Renal Registry, Indonesian Renal Registry; 2014.

4. Verdiyansah, Pemeriksaan Fungsi Ginjal, CDK-237, Bandung. Vol. 43; 2016. Available from: https://www. document/343902617/25-46-1-SM-3-pdf. [Last accessed on 2020 Jan 15].

5. Tanujiarso BA, Supriyadi I. The effectiveness of fluid diet counseling on controlling interdialytic weight gain (IDWG) of hemodialysis patients at Telogorejo Hospital, Semarang. J Nurs Midwifery. 2014;3:1-12.

6. Ariyanti FM. Pengaruh Self Efficacy Training Dengan Metode Peer Mentoring Terhadap Self Efficacy dan Kepatuhan Klien End Stage Renal Disease (ESRD) Yang Menjalani Hemodialisis, Tesis. Surabaya: Universitas Airlangga; 2016.

7. Thom DH, Ghorob A, Hessler D, Vore DD, Chen E, Bodenheimer TA. Impact of peer health coaching on glycemic control in low-income patients with diabetes: A randomized 
controlled trial. Ann Fam Med. 2013;11(2):137-44. https://doi. org/10.1370/afm.1443

\section{PMid:23508600}

8. Bistara DN. Coaching Support Terhadap Peningkatan Kepatuhan Penatalaksanaan Diabetes Mellitus Tipe 2, Tesis. Indonesia: Universitas Muhammadiyah Yogyakarta; 2015.

9. Arici M, editor. Management of Chronic Kidney Disease: A Clinician's Guide. New York: Springer; 2014.

10. Hadiyanti S. Pengaruh Self-Management Education Terhadap Kepatuhan Asupan Cairan Pada Klien Yang Menjalan Hemodialisis di RSUD Provinsi NTB, Tesis. Surabaya: Universitas Airlangga; 2017.

11. Alharbi K, Enrione BE. Malnutrition is prevalent among hemodialysis patients in Jeddah, Saudi Arabia. Saudi J Kidney Dis Transpl. 2012;23(3):598-608. PMid:22569456

12. Sumigar G, Rompas SS, Pondaag L. Hubungan dukungan keluarga dengan kepatuhan diet pada pasien GGK di Irina C2 dan C4 RSUP prof. DR. R. D. Kandou Manado. J Keperawatan. 2015;3(1):1-7. https://doi.org/10.35790/ecl.1.2.2013.3284

13. Baraz P, Mohammadi E, Braumand B. Dietary and fluid compliance: An educational intervention for patients having haemodialysis. J Adv Nurs. 2009;66(1):60-8. https://doi. org/10.1111/j.1365-2648.2009.05142.x

PMid:20423436

14. Mersal FA, El-Sedawy DS, Mersal NA. Effect of nursing guideline on dietary and fluid compliance among patients undergoing hemodialysis. J Health Med Nurs. 2016;26:35-47. Available from: http://www.iiste.org. [Last accessed on 2020 Jan 01].

15. Cooper S, Hall L, Penland A, Krueger A, May J. Measuring medication adherence. Popul Health Manag. 2009;12(1):25-30. https://doi.org/10.1089/pop.2008.0031

PMid: 19216676

16. Nugraha S, Nurhayati R. Hubungan Health Belief Dengan Perilaku Compliance Pada Pasien Gagal Ginjal Kronis di RSUD Al-Ihsan, Prosiding Psikologi; 2014. https://doi.org/10.37341/ jkg.v2i1.33

17. Patel ML, Sachan R, Noschal A, Surendra S. Anxiety and depression-a suicidal risk in patients with chronic renal failure on maintenance hemodialysa. Int J Sci Res Publ. 2012;2(3):1-6.

18. Clare L, Sharon J, Kate N, Natalie W, Hannah I. Health coaching in primary care: A feasibility model for diabetes care. BMC Fam Pract. 2014;15:60.

PMid:24708783

19. Browning C, Chapman A, Cowlishaw S, Li Z, Thomas SA, Yang $\mathrm{H}$, et al. The happy life Club ${ }^{\mathrm{TM}}$ study protocol: A cluster randomised controlled trial of a Type 2 diabetes health coach intervention. BMC Public Health. 2011;11:90. https://doi. org/10.1186/1471-2458-11-90

PMid:21303564

20. Vugt MV, de Wit M, Hendriks SH, Roelosfen $Y$, Bilo HJ Snoek FJ. Web-based self-management with and without coaching for Type 2 diabetes patients in primary care: Design of a randomized controlled trial. BMC Endocr Disord. 2013;13:53. https://doi.org/10.1186/1472-6823-13-53

PMid:24238104

21. Wolever RQ, Simmons LA, Sforzo GA, Dill D, Kaye $M$ Bechard EM, et al. A systematic review of the literature on health and wellness coaching: Defining a key behavioral intervention in healthcare. Glob Adv Health Med. 2013;2(4)38-57. https://doi. org/10.7453/gahmj.2013.042

PMid:24416684 